\title{
NOTE ON THE GENERIC NAME PECTUNCULUS.
}

\author{
By Dr. W. H. DaLL.
}

Read 14th June, 1912.

In an excellent reriew of the Lamarckian genus Pectunculus in the Journal de Conchyliologie for February, 1912 (p. 84), M. Ed. Lamy has some remarks on the synonymy of this genus, which seem to call for examination and revision.

I have elsewhere shown that Glycymeris, Da Costa, 1778, is the first name which can be used for Pectunculus, Lamarck, in conformity with the international rules for nomenclature.

M. Lamy states that “ce terme de Pectunculus a été employé avec un valeur générique, in 1770 par G. Huddesford, dans le preface d'une édition postérieure de Lister, puis il a été repris en 1799, par Lamarck".

One would naturally suppose that by 'preface' M. Lamy refers to Huddesford's 'Præfatio' of a page and a quarter, in which no generic names of any kind are mentioned, but in a letter M. Lamy has kindly informed me that he regarded not only the 'Præfatio' but all the indices as prefatory.

Two facts may easily be rerified by anyone having access to Huddesford's additions to Lister. First, he refers all the Lamarckian Pectunculi to Arca in his binomial index. Second, he uses the name Pectunculus in what may be claimed as a generic sense only once in the whole book, namely in the index to the anatomical plates, p. 5, tab. decima tertia, figure 1 ; and the species in connexion with which he uses it is Cardium edule, L. Consequently, if Pectunculus, Huddesford, has any standing in zoological nomenclature at all, it is a synonym of Cardium, Linné, and according to the rules of nomenclature cannot be used for any subsequently erected genus.

Pectunculus was used by Lister to cover nearly all the rounded and inflated bivalves, and not in particular for the Lamarckian Pectunculi.

I may add that the sole instance in which in his binomial index Huddesford introduces a name not previously in use by Linnæus is on p. 23, where he identifies Ostrea ephippium, L., with the genus Pedalion, Solander, which, if accepted, would preoccupy the later name Melina of Retzius (in Phillipsson), 1778.

\section{Supplementary Note.}

Since writing the preceding remarks I hare had another note from M. Lamy, who acknowledges that his views on the validation of the name Pectunculus, Lister, rest on the situation found on p. 6 of the alphabetically arranged summary of Lister's classification of the mollusca, printed as Index i of Huddesford's supplement. 
This is as follows: Lister's large groups being arranged alphabetically and the minor groups under them systematically, and nothing binomial in either.

"Pectunculi.

Fluviatiles . . . . . . tab. 157-60

Marines.

Paribus testis.

Polyleptoginglymi.

Margine longa seu ex altera Parte productiore tab. 229-38," etc.

If this may be taken as validating a generic name, Pectunculus, in the sense of binomial nomenclature, no one hereafter will dare mention a pre-Linnean name in any publication without a specific disclaimer. The above words, it must be remembered, are those of Lister and not of Huddesford. 


\section{$2 \mathrm{BHL}$ Biodiversity Heritage Library}

Dall, William Healey. 1912. "NOTE ON THE GENERIC NAME PECTUNCULUS." Proceedings of the Malacological Society of London 10, 255-256.

https://doi.org/10.1093/oxfordjournals.mollus.a063494.

View This Item Online: $\underline{\text { https://www.biodiversitylibrary.org/item/52423 }}$

DOI: https://doi.org/10.1093/oxfordjournals.mollus.a063494

Permalink: https://www.biodiversitylibrary.org/partpdf/203092

\section{Holding Institution}

Smithsonian Libraries

\section{Sponsored by}

Smithsonian

\section{Copyright \& Reuse}

Copyright Status: Public domain. The BHL considers that this work is no longer under copyright protection.

This document was created from content at the Biodiversity Heritage Library, the world's largest open access digital library for biodiversity literature and archives. Visit BHL at https://www.biodiversitylibrary.org. 